\title{
EVALUATION OF COST-OPTIMAL RETROFIT INVESTMENT IN BUILDINGS: THE CASE OF BRAGANÇA FIRE STATION, PORTUGAL
}

\author{
Sónia COVA (D), Carlos ANDRADE (D), Orlando SOARES (D), Jorge LOPES (D) * \\ Polytechnic Institute of Bragança, Bragança, Portugal \\ Received 12 November 2020; accepted 26 March 2021
}

\begin{abstract}
Office buildings built before the entry into force of the first thermal regulation in 1991 constitute a relevant group for analysing the energy performance of the Portuguese building sector. A dynamic energy simulation was used to assess the energy performance of an existing office building located in the town of Bragança, Portugal. Four energy efficiency measures were selected and a financial evaluation through the internal rate of return (IRR) method was undertaken to choose the best retrofit option for improving the building's energy performance. An investment package consisting of the roof insulation and a new equipment for the domestic hot water system presented an IRR higher than the discount rate used in the analysis, and, thus, a positive financial return. The results of the study also suggest that the EU's comparative methodology framework is not particularly suitable for assessing building retrofit investment at the private investor's perspective and further refinement in the cost-effective approach to renovations is needed to help stimulate building's energy renovation market. Suggestions for further studies conducted for office buildings in the different climate zones in Portugal are also proposed.
\end{abstract}

Keywords: building retrofitting, cost-optimality, dynamic energy simulation, economic assessment, energy performance, service building.

\section{Introduction}

Portugal, as a signatory of the Paris Climate Agreement, has committed to the EU's contribution to controlling greenhouse gas [GHG] emissions, limiting the increase in global temperatures to well below $2{ }^{\circ} \mathrm{C}$ during this century, with pre-industrial age levels taken as the benchmark (Government of Portugal, 2019). Globally, energy was responsible for about two thirds of GHG emissions in 2014 (Intergovernmental Panel on Climate Change [IPCC], 2015). In the European Union [EU], buildings account for about $36 \%$ of $\mathrm{CO} 2$ emissions and represent about $40 \%$ of energy consumption- the largest sector in all end- users area (European Parliament \& Council of the European Union, 2018a). The residential building segment alone represented about $27 \%$ of EU's final energy consumption in 2014 (European Parliament \& Council of the European Union, n.d.). However, the construction and property sectors represent the largest source of potential energy savings and GHG emissions reduction in Europe and worldwide (Bogdan \& Ilektra, 2013; IPCC, 2015; Kamari et al., 2019). In the mix of the building sector's energy consumption, operating (80-90\%) and embodied (10-20\%) phases of en- ergy use are significant contributors to building's life cycle of energy demand (Ramesh et al., 2010). Thus, an efficient strategy for the decarbonisation of the building sector has to encompass both the construction phase and the operating phase of buildings and other constructed facilities.

In the EU, the demand for energy for buildings is mainly caused by low levels of energy efficiency in buildings - around $75 \%$ of buildings are inefficient (Capros et al., 2016). This fact is also related to the construction period and it is estimated that $40 \%$ of residential buildings were built before 1960, a time when construction regulations were very limited (Economidou, 2011). Realising the potential associated with the building sector requires a strategy that should not be limited to stricter control in new building but should also provide more efficient solutions for existing buildings. With estimates showing that $75 \%$ - to $85 \%$ of the current EU building stock will still exist in 2050 (Fabbri et al., 2016), the renovation of the national building stock is a key element for attaining the EU's energy and climate goals.

The EU key policy instrument for reducing energy use in buildings is the Energy Performance of Buildings Directive $[\mathrm{EPBD}]$, accompanied by provisions for the building

*Corresponding author. E-mail: lopes@ipb.pt 
sector in other Directives, specifically the Energy Efficiency Directive [EED] and Renewables Energy Directive [RED] (Castellazi et al., 2019). The EPBD (2010/31/EU) states that Member States [MS] shall take the necessary measures to ensure that minimum energy performance requirements for buildings or building units are set with a view to achieving cost-optimal levels (European Parliament \& Council of the European Union, 2010). The EU Delegated Regulation No. 244/2012 (European Parliament \& Council of the European Union, 2012a), supplementing Directive 2010/31/EU, introduced a harmonised calculation methodology for calculating cost-optimal levels of minimum energy performance requirements for buildings and building elements. The Regulation prescribes that MS shall report to the European Commission all input data and assumptions used in those calculations. The EED (2012/27/EU) also includes a number of measures targeting energy efficiency improvements in buildings (European Parliament \& Council of the European Union, 2012b). These include the requirement for Member States to establish a long-term renovation strategy [LTRS] for mobilising investment in the renovation of the national stock of residential and commercial buildings, both public and private. The Article 4 of the EED states that the LTRS shall identify the cost-effective approaches (according to the comparative methodology of the $\mathrm{EPBD}$ ) to renovation relevant to the building type and climatic zone. They shall also present the main policies and measures (including financial and tax instruments) to stimulate cost-effective deep renovations of buildings, including staged deep renovation, and a forward-looking perspective to guide investment decisions of individuals, the construction industry and financial institutions (European Parliament \& Council of the European Union, 2012b).

Financial incentives have been developed (at EU and national levels) to improve the access to capital but they have also been developed to motivate consumers to take energy efficiency actions. The financial instruments normally include subsidy/grant schemes, soft loans and funds (Economidou \& Bertoldi, 2014; Government of Portugal, 2019). The subsidy/grant schemes are generally target to meet specific objectives and to promote deep renovations (generally public and residential buildings), which have high investment costs (Economidou \& Bertoldi, 2014). However, achieving economic efficiencies in the energy renovation market is complex. There are many barriers faced by the sector, from technical barriers to regulatory and market risks. A special report of the European Court of Auditors [ECA] suggested that cost-effectiveness is not a determining factor for public funding of energy efficiency in buildings (ECA, 2020). In the reply to the ECA report the European Commission recognised that investments in energy efficiency are project-specific and related to several factors (state of the building, climatic conditions, labour costs, energy costs, material costs, type of use, etc.) which cannot be standardised. And that simple upgrades with high energy savings per euro invested are usually financially viable and should therefore generally be financed by the private market (ECA, 2020). Following this line, it appears that staged renovation needs a fresher look from the part of national governments in the EU.

The pattern of energy consumption in Portugal is markedly different from that of the EU as a whole. In Portugal, in 2016, the transport sector was the main contributor with $37 \%$, followed by industry (31\%), building (29\%); divided into residential (16\%) and service buildings (13\%); and agriculture and fisheries (3\%) (Portuguese Energy Agency [ADENE], 2018). The primary energy consumption in Portugal totalled $22.1 \mathrm{Mt}_{\mathrm{oe}}$ in 2016. Compared with the mix of energy consumption registered in 2006 , the two segments of the building sector, residential and service buildings, had, negative annual growth rates of $-2.6 \%$ and $-1.0 \%$, respectively. The industry sector experienced, in the same period, an average annual growth rate of $-3.2 \%$ and that of transport was $-2.4 \%$. Despite this somewhat bleak picture, particularly that of service buildings, the country is expected to have achieved the national target in primary energy consumption for 2020, within the provisions set up in the Annex XIV of the EED (European Parliament \& Council of the European Union, 2018a; Government of Portugal, 2019). The evolution pattern of GHG emissions has presented a more promising prospect. Following the rapid growth in GHG emissions in the 1990s, Portugal reached its peak of national GHG emissions in 2005, after which they have recorded a significant and sustained fall, consolidating the trend of decarbonisation of the economy. In 2017, according to the most recent update of the 2019 National Emissions Inventory (Government of Portugal, 2020a), GHG emissions, without considering those due to land use changes and forests, were estimated at about $70.7 \mathrm{Mt} \mathrm{CO}_{2} \mathrm{eq}$, which represented a decrease of $22.5 \%$ compared to 2005 , and $17 \%$ below the Kyoto Protocol target.

Office buildings built before the entry into force of the first thermal regulation in 1991 (Government Gazette, 1990) constitute a relevant group for assessing the energy performance of the Portuguese building sector. The country's built-up area comprised around $452,000,000 \mathrm{~m}^{2}$ in 2014, of which, 77\% was represented by residential buildings (European Parliament \& Council of the European Union, 2016). The service segment is broken down in the following subsegments: private and public offices (26.6\%); schools (20.1\%); hospitals (6.9\%); hotels and restaurants (13.5\%); sports buildings (4\%); commerce (27.2\%); and other (1.7\%). There are no available data on the number of non-residential buildings according to the construction period. It is assumed, here, that the evolution pattern across construction periods in this segment was similar to that of the residential building. It was also assumed that half of the buildings built in the 1990s did not meet the requirements set out in the thermal regulation. Thus, office buildings built without thermal performance requirements constitute about $20.1 \%$ of the country's total nonresidential segment or around 20,906,000 $\mathrm{m}^{2}$ of gross floor 
area. It is also worth noting that final energy consumption in service buildings has remained practically stagnant in the period 2011-2016, and office buildings were responsible for about $38 \%$ of the non-residential segment's final energy consumption in 2016 (Government of Portugal, 2019). Thus, an effective strategy for energy renovation of this building cluster can make a great contribution to achieving the energy and climate targets envisaged for 2050 .

The LTRS, in a number of EU countries (including Portugal), do not present a detailed information (if any) on the cost-effective approaches to renovations and priority groups of buildings nor do they provide a comprehensive analysis of the barriers to investment (Castellazi et al., 2019). Like most of energy efficiency programmes prevailing in the EU, the economic instruments to stimulate building's energy renovation market in Portugal are generally target for existing residential and public buildings (Directorate-General for Energy and Geology [DGEG], 2019). As the service building segment's final energy consumption in Portugal is not much dissimilar to that of the residential buildings, an approach focused on the former segment may provide new insights for assessing the consistency of Portugal's strategy for energy efficiency. The aim of the research is to explore the evaluation of energy building retrofits from a cost-effectiveness approach, within the context of the EU and Portugal's regulatory and policies frameworks for energy efficiency of the building sector. The paper used as a case study an existing large office building, located in the town of Bragança in Northeastern Portugal, to assess the financial viability of different energy efficiency measures/packages to select the best retrofit option for improving the building's energy performance.

The remainder of the paper is presented as follows: the EU and Portugal's regulatory and policies frameworks for energy efficiency of the building sector are presented in Section 1; Section 2 provides a brief review on the cost optimality of energy renovation investment; the methodology is presented in Section 3; Section 4 presents the results of the dynamic simulation of the building; the financial analysis of selected energy efficiency measures is provided in Section 5; and concluding remarks are drawn in the last section.

\section{Context}

The first policy initiatives and measures targeting energy performance of buildings and energy efficiency in Europe take place in the late 1970s-early1980s in a number of countries (e.g. France, Denmark, the then Federal Republic of Germany and the Netherlands). However, the trigger point at the EU level was the entry into force of the EPBD in 2002 (European Parliament \& Council of the European Union, 2002), followed by the implementation of Energy Services Directive in 2006 (European Parliament \& Council of the European Union, 2006), replaced by the EED in 2012. The recent publication Green Energy for all Europe- ans Package (European Parliament \& Council of the European Union, 2019) encapsulates, in a more comprehensive and integrated way, the EU's policy framework in the area of energy. It consists of eight legislative acts in the domains of energy efficiency, renewable energy, governance regulation, electricity market, and international cooperation, which will be transposed into national law by MS in 2020-2021. Particularly of interest for energy efficiency of the building sector, were the amendments of the EED (European Parliament \& Council of the European Union, 2018a), the EPBD (European Parliament \& Council of the European Union, 2018b) and the RED (European Parliament \& Council of the European Union, 2018c). The paradigm shift that was firstly reflected in the EPBD in 2002 and, particularly, in its amendment in 2010, was significantly reinforced in this set of legislative initiatives, setting up clear milestones for the years 2030, 2040 and 2050. The stated aim was to enhance the measures that reduce the impact of global energy consumption by encouraging the rational use of energy sources, while maintaining or increasing the conditions of thermal comfort and indoor air quality, and addressing the problem of energy poverty in the less affluent strata of society.

Portugal, although a late mover in terms of energy efficiency, has rapidly been catching up in this arena, both in terms of regulatory framework and in terms of efficiency programmes. In the residential and service segments, three energy efficiency programmes have been implemented (Fragoso \& Baptista, 2016; ADENE, 2018): Home Renewable Programme, which addresses measures involving lighting, electrical appliances, consumer electronics and building envelope in residential buildings; Energy Certification of Buildings, aiming at the improvement of residential and services building's needs and; Renewable at the Time Programme, which covers the area of own-production energies in residential and service building segments. With respect to the regulatory framework, the EPBD was first transposed into national law in 2006, based on three decree-laws, each of them covering one of three separate areas: Building Energy Certification System-SCE (Government Gazette, 2006a); Energy Performance in Commercial and Service Buildings (Government Gazette, 2006b); and Energy Performance in Residential Buildings (Government Gazette, 2006c). This set of legislation was amended in 2013 to transpose in a single diploma - Decree-Law No. 118/2013 (Government Gazette, 2013a) - the tighter requirements of the Directive 2010/31/EU. The revision was mainly aimed at the improvement in the calculation methodologies for energy needs and in the certification process. The latter involved the upgrading of the national SCE that included the development of a new online platform to issue energy performance certificates (EPCs), a new website and support documentation and guidelines for energy certification experts. The main goal was to realign the SCE with the needs of the market, particularly linking improvements on the EPC scale with funding eligibility and tax benefits (Fragoso \& Baptista, 2016). Successive amendments of the Decree-Law No. 118/2013 and 
of the ancillary legislation were enforced to phase in more restrictive minimum energy performance requirements in new buildings (from 2021 onwards all new buildings must be nearly zero-energy buildings), building undergoing major renovations and replacement of building components and technical systems in existing buildings. For existing service buildings, the methodologies for determining the energy performance are through its real energy consumption or by using dynamic multi-zone simulation. The latter methodology requires the use of a software accredited by the ASHRAE Standard 140. Another important development concerning the service building segment is that existing buildings that have heated floor area greater than $1.000 \mathrm{~m}^{2}$ and an energy class D or lower on the EPC scale are subject to an Energy Rationalisation Plan (PRE). The plan, under the responsibility of a qualified expert, consists of a set improvement measures to be implemented in the building, so that its upgrading in energy efficiency will be at least in the energy class C on the EPC scale.

\section{A brief review on the cost-optimality of energy renovation investment in buildings}

Economic evaluation of public investment takes place in the United States in the early 1980s, in the aftermath of the second oil shock in 1979-1980 (Ruegg \& Marshall, 1990). The Building Economics Subcommittee was established in 1979 within the ASTM Committee E06 on the Performance of Buildings (Kasi \& Chapman, 2012). As noted earlier, building and other constructed facilities are responsible for the largest share of energy consumption in the EU and other industrially advanced regions of the world. It is also well known that energy prices have a significant impact on the costs of building materials and construction equipment. This rationale was enshrined in the EPBD comparative methodology framework as the basis for the MS to compare their minimum energy performance requirements levels against cost optimal levels. The article 2 of the EPBD defines cost optimal level as "the energy performance level that leads to the lowest cost during the estimated economic life cycle of a building or building element". The comparative methodology involves the following steps as defined in the EU Delegated Regulation No. 244/2012: 1) establishment of the reference buildings (RB) for different types of residential and service buildings, for both new and existing buildings; 2) identification of energy efficiency measures/packages for each $\mathrm{RB}$; 3) calculation of the primary energy demand resulting from the application of such measures/packages to an $\mathrm{RB}$ and; 4) calculation of the life cycle cost (global cost) in terms of the Net Present Value (NPV). If the results of this comparison show that current energy requirements are significantly less energy efficient than cost-optimal levels, then the MS are required to justify this difference.

The life cycle cost of building/building element comprises the following costs: the initial investment cost; running cost (minus relevant benefits, if any), including replacement cost of building elements; cost of energy prices; and disposal cost, if appropriate. These are calculated considering the time value of money i.e. the discount rate. It is up to the discretion of the MS to calculate the global cost at the macroeconomic perspective (i.e. including externalities costs, for example $\mathrm{CO}_{2}$ emissions) or at the financial perspective. The global cost can also be seen at the macro level (social) or at the end-user (micro) perspectives. As regards the reference building (RB), in each category, there are two methodologies for creating an RB: the $\mathrm{RBr}$ methodology, in which a real building representing the most typical building in each category is selected and; the $R B v$ methodology, which consists in the creation of a virtual building which, for each relevant parameter, includes the most commonly used materials and building systems. In the latter methodology, the relevant information is either based on expert's advice or on statistical data, or a combination of both (Tadeu et al., 2016). The trickiest aspect of the framework methodology is the choice of the discount rate. It is usually set up in real terms i.e. not considering inflation throughout the economic life of the building/building system. At the macro level, it depends on a country's macroeconomic fundamentals as well as on the interest rates set up by national central banks or by the European Central Bank. At the micro level, it tends to reflect the conditions of the market price of capital. Within this concept, the discount rate at the perspective of a private non-commercial investors is, usually, lower than that of a property investor (Bogdan \& Ilektra, 2013). Steinbach and Staniaszek (2015) and Hermelink and de Jager (2015) provided a review of the discount rates prevailing in some European countries and US, at both macro level and micro level perspectives.

As part of Portugal's obligations contained in the article 5 of the EPBD, two sets of government-commissioned reports (DGEG, 2013; Pinto, 2014; DGEG \& ADENE, 2019; Aguiar \& Graça, 2019) used the comparative methodology to assess the cost-optimal levels of energy efficiency measures/packages for residential, office and hotel buildings. Also, at the macro-level, Vasconcelos et al. (2015) used the $R B v$ methodology, based on statistical data and expert's opinion, to analyse the cohort of Portuguese residential buildings built between 1961 and 1990. Financial evaluations of energy-related investment in the country's building sector has also been dealt with at the private investor perspective (Rodrigues et al., 2015; Ferreira et al., 2016; Tadeu et al., 2015, 2016). Tadeu et al. (2016) also followed the $R B v$ methodology and a multi-objective optimization approach to identify the minimum global cost and primary energy needs of several combinations of energy efficiency measures. Using, as a case study, a two-bedroom single-family dwelling built before 1960 in the North of Portugal, they then compared, at the private investor perspective, the cost-optimal levels and a return on investment (ROI) for a set of suitable solutions for the reference building. Rodrigues et al. (2015), took for case study a 19 th century stone masonry residential building, located 
in O'porto city, to assess the applicability of the EnerPHit standard in existing buildings. The reference solution was then studied in six climate zones in the North and Centre of the Portugal mainland. They founded that an energy efficiency measure consisting of an XPS solution had a discounted pay-back between 11 and 12 years and a vacuum insulation panel solution had a discounted pay-back of more than 30 years, in all climate zones analysed. To the best of our knowledge, there has been no published work (at least in scholarly international journals) dealing with the financial viability of energy retrofitting of Portugal's office building subsegment. This study aims to contribute to fill this gap.

\section{Methodology}

This research aims to explore the evaluation of energy building retrofits from a cost-effectiveness approach, with reference to a single case study that is representative of a particular building cluster. In the first step of the study, the EU and Portugal's regulatory and policies frameworks for energy efficiency of the building sector were reviewed. This included the EU's harmonised methodology for calculating cost-optimal levels of energy performance requirements. Next, a financial analysis through the IRR method combined with a dynamic energy simulation was undertaken to determine the energy performance of the building, considering two alternatives: the building "without project"); and energy retrofitting of the building with different energy efficiency measures/packages. The energy efficiency measures consisted of three passive technologies applied to the building envelope and an energy-efficient domestic hot water equipment. For each of efficiency measures/packages, the following parameters were identified: initial investment cost; operation and maintenance cost; the equipment's residual values at the end of the period of analysis and; incurred savings. These savings were calculated as the difference between the energy consumption of different energy vectors (electricity and natural gas) of the building "without project" and that of the building implement with different energy efficiency measures/packages. The study period was set at 30 years.

The following subsections present: the building geometry, building location and thermal characterisation of the building envelope; the climate zone; the characteristics of the building technical systems and; the data and assumptions used to run several energy simulations.

\subsection{Case study building}

The building under study is the Bragança Fire Station, located in the town center of Bragança, at an altitude of $717 \mathrm{~m}$ and a distance to the coast of about $173 \mathrm{~km}$. The building is $40 \mathrm{~m}$ wide, East-West, and $70 \mathrm{~m}$ long, Northwest-Southeast, with its main façade facing Northeast (Figure 1). The location is part of the coldest winter zone of Portugal mainland. The year of construction is 1991, which coincided with the date of entry into force

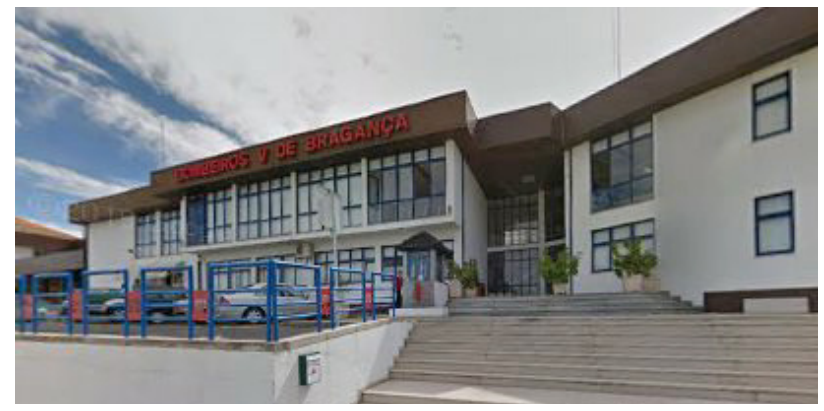

Figure 1. Main façade of the building

of the first thermal regulation in Portugal. However, the building was exempt from the requirements set out in the regulation for the building permit was issued in 1990. The building has been subject to minor interior renovations, in terms of dressing rooms, bathrooms, living room and bar. It has also undergone changes in the interior and exterior lighting system, placement of air conditioning equipment in widely used spaces and replacement of the old glazing with a new one with better thermal characteristics. The building has a light-colored exterior surrounding, spreading over two floors with vertical connection bridged by stairs. It has a total interior area of $2.716 \mathrm{~m}^{2}$, a useful area of $1.362 \mathrm{~m}^{2}$, of which $340 \mathrm{~m}^{2}$ with heating and cooling systems. For the study, it was considered that the whole useful area is heated (see Appendix A). Thus, this is the project baseline for assessing the financial viability of the interventions.

The thermal characterization of the building envelope, namely the building parameters and the thermal transmission coefficient of the walls and slabs was performed according to the Ministerial Decision No. 15793-E/2013 (Government Gazette, 2013b). This legal document established a simplification procedure to be used in services building undergoing major renovations, as well as in existing buildings. Unable to have data on the components of walls, roofs and floors, the default values for this type of construction were used in the calculations. The reference publication ITE 50 from the Portuguese National Laboratory for Civil Engineering (Santos \& Matias, 2006) provides the reference values for all building elements, such as glazing and outer covering. Regarding the glazing, five different types were observed. Using a glass thickness gauge, it was possible to check the thickness of the glass and the air boxes present in the glazing. The thermal transmission coefficient and solar glass factor of the different types of glazing are presented in Table 1.

The characteristics of the opaque wall elements of the building are as follows:

- Exterior wall - with a thickness of $36 \mathrm{~cm}$. According to the provisions of the Ministerial Decision No. 15793-E/2013, a plastered wall put in place after 1960, either single or double walls, has a coefficient of thermal transmission of $0.96 \mathrm{~W} / \mathrm{m}^{2}$;

- Exterior covering - horizontal heavy cover with a thermal transmission coefficient of $2.6 \mathrm{~W} / \mathrm{m}^{2}{ }^{\circ} \mathrm{C}$; 
Table 1. Thermal transmission coefficient and solar glass factor of the glazing

\begin{tabular}{|c|c|c|c|}
\hline Glazing type & $\begin{array}{c}\text { Thermal } \\
\text { transmission } \\
\text { coefficient } \mathrm{U} \\
{\left[\mathrm{W} / \mathrm{m}^{2}{ }^{\circ} \mathrm{C}\right]}\end{array}$ & $\begin{array}{c}\text { Solar glass } \\
\text { factor }\end{array}$ & $\begin{array}{c}\text { Solar glass } \\
\text { factor with } \\
\text { protection }\end{array}$ \\
\hline GL1 & 3.54 & 0.78 & - \\
\hline GL2 & 2.62 & 0.78 & 0.09 \\
\hline GL3 & 4.14 & 0.78 & 0.385 \\
\hline GL4 & 6.2 & 0.88 & - \\
\hline GL5 & 6.3 & 0.88 & - \\
\hline
\end{tabular}

- Outer covering - consists of fiber-cement plates with a thermal conductivity coefficient of $0.65 \mathrm{~W} / \mathrm{m}{ }^{\circ} \mathrm{C}$, resulting in a thermal transmission coefficient of $6.436 \mathrm{~W} / \mathrm{m}^{2}{ }^{\circ} \mathrm{C}$;

- Outdoor slab - heavy floor with a thermal transmission coefficient of $3.1 \mathrm{~W} / \mathrm{m}^{2}$.

\subsection{Climate zone}

Climate zoning in Portugal is presented at the Level III of the Nomenclature of Territorial Units for Statistical Purposes (NUTS). Its composition by municipality is detailed in the Ministerial Decision No. 15793-F/2013 (Government Gazette, 2013c). The building under study is located in Bragança, which corresponds to the NUTS III Alto Trás-os-Montes. Applying the Equations (1) and (2), as described in the Ministerial Decision No. 15793-F/2013, the climate zone of the building is determined.

$$
H D D=H D D_{r e f}+a\left(z-z_{r e f}\right)
$$

where: $H D D_{r e f}$ is the reference heating degree day, on the basis of $18{ }^{\circ} \mathrm{C}$, corresponding to the conventional heating season of $2.015^{\circ} \mathrm{C}$; $a$ is the slope for altitude adjustments, $1.400{ }^{\circ} \mathrm{C} / \mathrm{km} ; z$ is the altitude of the building location, $717 \mathrm{~m} ; z_{\text {ref }}$ is the reference altitude of $680 \mathrm{~m}$.

The resulting value is $2.066 .8^{\circ} \mathrm{C}$, which corresponds to zone W3 according to Table 2.

$$
\theta_{\text {ext }, v}=\theta_{\text {ext }, v r e f}+a\left(z-z_{\text {ref }}\right) \text {, }
$$

where: $\theta_{\text {ext, } v \text { ref }}$ is the reference outdoor temperature corresponding to the conventional cooling season, $21.5^{\circ} \mathrm{C}$; $a$ is the slope for altitude adjustments, $-4{ }^{\circ} \mathrm{C} / \mathrm{km} ; z$ is the altitude of the building location, $717 \mathrm{~m} ; z_{\text {ref }}$ is the reference altitude of $680 \mathrm{~m}$.

The resulting value is $21.35^{\circ} \mathrm{C}$, which corresponds to zone $\mathrm{S} 2$ according to Table 3.

Table 2. Criterion for determining the winter climate zone

\begin{tabular}{|l|c|c|c|}
\hline Criterion & HDD $\leq 1.300$ & $\begin{array}{c}1.300<\mathrm{HDD} \leq \\
1.800\end{array}$ & HDD $>1.800$ \\
\hline Zone & $\mathrm{W} 1$ & $\mathrm{~W} 2$ & $\mathrm{~W} 3$ \\
\hline
\end{tabular}

\begin{tabular}{|c|c|c|c|}
\hline Criterion & $\theta_{\text {ext }, v} \leq 20^{\circ} \mathrm{C}$ & $\begin{array}{c}20^{\circ} \mathrm{C}<\theta_{\text {ext }, v} \leq \\
22{ }^{\circ} \mathrm{C}\end{array}$ & $\theta_{\text {ext, } v}>22^{\circ} \mathrm{C}$ \\
\hline Zone & S1 & S2 & S3 \\
\hline
\end{tabular}

Table 3. Criterion for determining the summer climate zone

\subsection{HVAC system}

The HVAC system consists of eight air conditioning equipment. For each unit, it was necessary to obtain their heating and cooling efficiency data, like the Energy Efficiency Ratio-EER and Coefficient of Performance - COP (Table 4).

Table 4. COP and EER for different air conditioner models and their location

\begin{tabular}{|l|c|c|c|}
\hline \multicolumn{1}{|c|}{ Model } & Location & COP & EER \\
\hline Tango PI 18-410-IG & Medical room & 3.8 & 5.6 \\
\hline Whirlpool SPIW 418L & Men's bedroom & 3.8 & 5.6 \\
\hline Whirlpool SPIW 422/2 & Classroom & 4 & 6.3 \\
\hline Indesit MONO INV 24I7 & Women's bedroom & 3.61 & 3.21 \\
\hline Haier HSU-09HD03/ R2 & $\begin{array}{c}\text { Central } \\
\text { communications }\end{array}$ & 3.63 & 3.23 \\
\hline Whirlpool SPIW 318L & Living room & 4 & 6 \\
\hline Whirlpool SPIW 412L & Secretary & 3.8 & 5.6 \\
\hline Tango PI 24-410-IG & Director's office & 3.8 & 5.1 \\
\hline
\end{tabular}

In the simulation, the heating set points were between $17^{\circ} \mathrm{C}$ and $20^{\circ} \mathrm{C}$, according to the provisions of Portuguese legislation regarding ideal comfort in buildings. A natural gas boiler with continuous operation was used, with an efficiency of $89 \%$, because this is the regulatory minimum requirement. The sanitary hot water system comprises cylinders of 50, 150 and 200 litres of capacity, which are placed at strategic points of use, like the changing rooms and kitchens. A survey was made of all other building's electrical equipment. For instance, the equipment in the catering area consists of refrigerators, freezers, refrigerating cabinets and coffee machines. Radio and flashlight carriers as well as a vehicle lift and a compressed air bottle carrier belong to the group of equipment inherent to the fire services. The office equipment comprises a server, computers, fax, printers, monitors, projectors, televisions and a video surveillance system.

\subsection{Dynamic energy simulation}

EnergyPlus, which is a program accredited by ASHRAE Standard 140 (American Society of Heating, Refrigerating and Air-Conditioning Engineers [ASHRAE], 2017) was the energy simulation software used in the study. In the simulation, the following data were collected for each room: type of space; the average occupation rate and the average utilisation rate; the power capacity of lighting systems and their operation schedule and; the heating and 


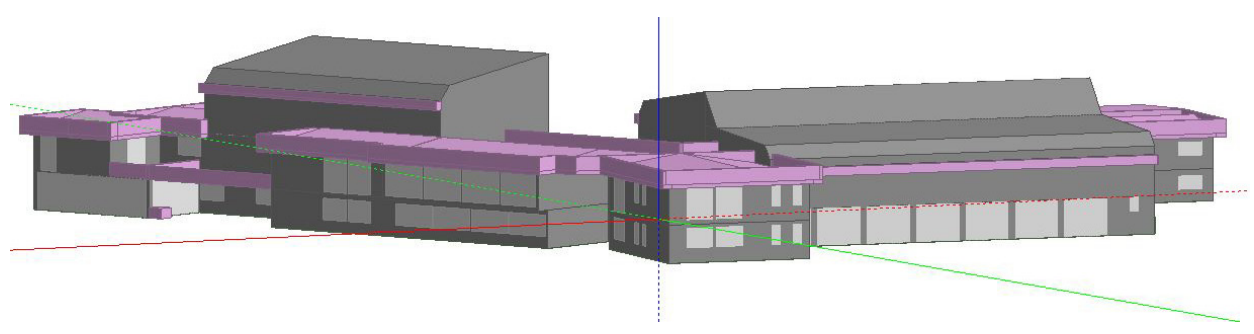

Figure 2. Building Northeast view

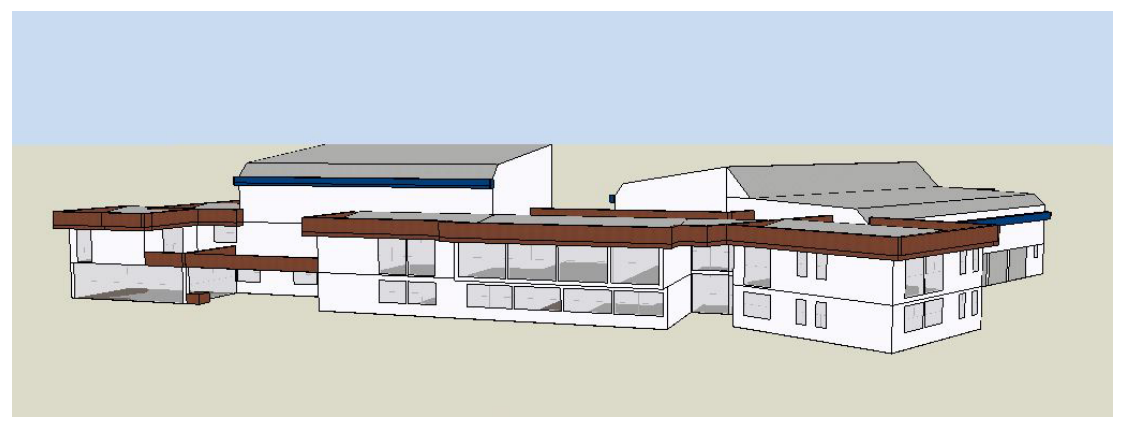

Figure 3. 3D model of the building in view mode

cooling systems and their operation schedule. To run several simulations needed to assess the energy performance of the building "without project" and that of the building implemented with each one of the efficiency measures, it was necessary to create a 3D building model in the DesignBuilder, which is a graphical user interface of EnergyPlus. The 3D model was intended to represent the actual building operating conditions as well as their construction characteristics, which makes the simulation as reliable as possible. After properly treating the building plans by using the AutoCAD ${ }^{\circ}$ software, the plans were exported to the DesignBuilder. After drawing the contours of each slab, creating blocks and overlapping them to shape the building, the glazed spans and doors were then created. The fibre-cement panels of the roof are represented as component blocks as they cause shading to the building (Figure 2).

In the 3D model, each floor was divided into zones according to the Ministerial Order No. 349-D/2013 (Government Gazette, 2013d) for multi-zone simulations. It was also necessary to characterise each area according to its use, occupation and illuminance. The model was finalized with the definition of the different types of floor slabs, roofs slabs, walls, glazing and lamps, as well as the heating, cooling and sanitary hot water systems. Figure 3 presents the set of the building surrounding colours, shading and other relief details in the DesignBuilder view mode.

\section{Results of the energy simulation}

Apart from the results of the simulation, the energy consumption of two lamps located at the exterior of the building were also considered. One lamp is a lamppost with a night clock controller and the other one is used occasionally in the vehicles washing area only. The annual energy consumption of these luminaires was 12,066 KWh.
Table 5 presents the final energy consumption by type of building technical system.

Table 5. Final energy consumption by type of building technical system (KWh)

\begin{tabular}{|l|c|}
\hline Lighting & $23,421.49$ \\
\hline Equipment & $60,156.22$ \\
\hline Cooling & $5,894.48$ \\
\hline Heating & $147,065.29$ \\
\hline Domestic hot water (DHW) & $10,958.70$ \\
\hline Total & $247,496.2$ \\
\hline
\end{tabular}

The technical analysis of the energy efficiency measures was dealt with in a previous study (Lopes \& Cova, 2018). What is worth pointing out here is that investment decisions for building retrofitting are irreversible and once a decision is taken, this should not interfere with more efficient and low-cost solutions that are expected to occur in the medium-to-long term horizon (Conci et al., 2019). The energy efficiency measures analysed in the study were as follows:

- EM1 - placement of ETICS panel with $15 \mathrm{~cm}$ thickness on the outer walls and outer floor;

- EM2 (roof insulation) - placement of sandwich panel with $6 \mathrm{~cm}$ insulation, replacing the asbestos cover in the entire floor. Additionally, an $8 \mathrm{~cm}$ thick XPS insulation is applied over the slab;

- EM3 (roof insulation) - replacement of the asbestos cover in the entire floor. Placement of a sandwich panel with $6 \mathrm{~cm}$ insulation in the car park areas and in the salon floor. A $12 \mathrm{~cm}$ thick XPS panel with a regularization layer and PVC screen is placed on the remainder of the floor;

- EM4 - replacement of the electric cylinders for aerothermal heat pumps. 
Table 6 presents the final energy consumption of the building implemented with the energy efficiency measures EM1 to EM4.

Table 6. Final energy consumption of the building with the efficiency measures EM1 to EM4 (KWh)

\begin{tabular}{|c|c|c|c|c|}
\hline & EM1 & EM2 & EM3 & EM4 \\
\hline Lighting & $23,421.49$ & $23,421.49$ & $23,421.49$ & $23,421.49$ \\
\hline Equipment & $60,156.22$ & $60,156.22$ & $60,156.22$ & $60,156.22$ \\
\hline Cooling & $5,735.07$ & $6,931.05$ & $7,991.33$ & $5,894.48$ \\
\hline Heating & $135,052.43$ & $116,812.74$ & $114,301.78$ & $147,065.29$ \\
\hline DHW & $10,529,51$ & $10,958.7$ & 10958,7 & $3,635.57$ \\
\hline $\begin{array}{l}\text { Total con- } \\
\text { sumption }\end{array}$ & $234,894.7$ & $218,280.2$ & $216,829.5$ & $240,173.1$ \\
\hline $\begin{array}{l}\text { Energy } \\
\text { savings - } \\
\text { Natural gas } \\
\text { (NG) }\end{array}$ & $12,012.86$ & $30,252.55$ & $32,763.51$ & - \\
\hline $\begin{array}{l}\text { Energy sav- } \\
\text { ings - Elec- } \\
\text { tricity (E) }\end{array}$ & 588.60 & - & - & $7,323.13$ \\
\hline $\begin{array}{l}\text { Additional } \\
\text { consump- } \\
\text { tion (E) }\end{array}$ & - & $1,036.57$ & $2,096.85$ & - \\
\hline
\end{tabular}

\section{Evaluation of the energy retrofit investment}

\subsection{Method of financial evaluation and assumptions}

There are several methods for measuring the economic performance of a building/building element investment. As stated earlier, the EU's comparative methodology framework uses the Life Cycle Cost (LCC) method to choose the least global cost of different energy efficiency measures/packages and then compare the cost-optimal energy performance levels with the minimum requirement levels. Either the net saving (NS) method, which is a variant of the net benefit method, or the internal rate of return (IRR) method could be applied to assess the financial viability of the proposed interventions. However, at the private investor's perspective, the IRR method is more informative. The IRR measures the percentage yield of an investment. It is then compared against the investor's minimum acceptable rate of return (or reasoned by the average long-term capital market interest rates) to ascertain the economic/financial attractiveness of the investment. The IRR formula is presented in Equation (3).

$$
P V N S_{A 1: A 2}=\sum_{t=0}^{N} \frac{S_{t}-\left(I_{t}+M_{t}+R p_{t}\right)+R V_{N}}{(1+I R R)^{t}}=0,
$$

where: $P V N S_{A 1: A 2}$ - present value of net savings of alternative $A_{1}$ when compared with a mutually exclusive alternative, $A_{2} ; S_{t}$ - savings in year $t$ of $A_{1}$ less those of $A_{2} ; I_{t}$ - investment costs in year $t$ of $A_{1}$ less those of $A_{2}$; $M_{t}$ - operation and maintenance costs in year $t$ of $A_{1}$ less those of $A_{2} ; R p_{t}$ - replacement costs in year $t$ of $A_{1}$ less those of $A_{2} ; R V_{N}$ - residual value in year $N$ of the study period of $A_{1}$ less that of $A_{2} ; N$ - number of years in the study period $I R R$ - internal rate of return, i.e. a discount rate for which $P V N S=0$.

As pointed out earlier, discount rates are a crucial economic parameter in energy system analysis. Individual discount rates are estimated to model investment decisionmaking that reflects the expected return of an investor. In their work commissioned by Building Performance Institute Europe [BPIE], Steinbach and Staniaszek (2015) pointed out that social discount rates in the MS national reports are set up in a range between 1 and 7\%, as measured in real terms. For private investors (non- commercial and nonindustrial investors, including the household sector), they recommended a real discount rate in a range between 3 and 6\%. In the Annex 1 of the EU Cost-Optimality Delegated Regulation, it is set that Member States "have to determine the discount rate to be used in the macroeconomic calculation after having performed a sensitivity analysis on at least two different rates, one of which shall be $3 \%$ expressed in real terms" (European Parliament \& Council of the European Union, 2012a, cited in Bogdan \& Ilektra, 2013). The Portuguese national report (DGEG \& ADENE, 2019) used real discount rates of $3 \%$ and $1.5 \%$ in the sensitivity analysis, for both the macroeconomic and financial calculations. A recent study dealing with the renovation of the national building stock in Portugal (Government of Portugal, 2020b) used a nominal discount rate of $2.52 \%$ for the financial analysis. As the building owner's organisation is a non-commercial private investor, an estimation of the discount rate tends to come near of the lower tier of Steinbach and Staniaszek's (2015) discount rate range. Thus, a real discount rate of $4 \%$ seems to be reasonably constructed. As regards the relation between the selection of the discount rates and energy price developments, it is worth noting that, in the rationale of financial assessment, the present value of energy costs (net savings in this case) decreases with increasing time along the study period if the discount rate is higher than the growth rate of energy prices, both expressed in real terms. This research followed previous works (e.g. Conci et al., 2019), that adopted constant (in real terms) energy prices along the study period to account for the volatility in the energy market. This price development corresponds to the "low energy price" scenario used in most MS national reports. Energy prices are taken from the Pordata database (Pordata, 2020). The average prices of electricity and of natural gas in 2019 were, respectively, $0.215 € / \mathrm{KWh}$ and $0.076 € / \mathrm{KWh}$ and it was assumed that these prices will remain the same for 2021, the beginning of the study period. This was set at 30 years, ending in 2050.

\subsection{Costs of the efficiency measures}

The Cype Ingenieros database (Cype Ingenieros, 2020) provides prices of building materials for both new and renovation works. The material and application costs of EM1 was $45 € / \mathrm{m}^{2}$, which made a total investment cost of $94,817.55 €$. Considering the material and application costs 
of a $6 \mathrm{~cm}$ thick sandwich panel at $30 € / \mathrm{m}^{2}$; and $19 € / \mathrm{m}^{2}$ and $26 € / \mathrm{m}^{2}$ for the material and application costs of XPS with thicknesses of, respectively, 8 and $12 \mathrm{~cm}$; plus $25 € / \mathrm{m}^{2}$ for applying a regular layer and PVC screen, the total cost of EM2 amounted to $80,222.83 €$ and that of EM3 amounted to $76,476.12 €$. The cost of the metal sheet panel must be deducted from both the EM2 and EM3 total costs. The former is the replacement cost of the existing asphalt roof cover, which by law is a mandatory intervention. Thus, the total costs of EM2 and EM3 for the financial analysis of this study were, respectively, 51,292.58 $€$ and $47,545.87 €$. The investment costs of EM4 (5,600 €, including additional piping works) were taken from equipment suppliers. As it is usual in this kind of financial analysis, the maintenance and operation costs that occur in all considered alternatives (including the "without project" one) were not taken in consideration. The useful lives of EM1, EM2 and EM3 were set at 30 years, so no residual value was considered for these efficiency measures. For EM4 (aerothermal heat pumps), the useful life was set at 20 years and the residual value was calculated by using the linear depreciation method. The annual maintenance and operation costs were set at $2.5 \%$ of the investment cost.

\subsection{Financial return of the energy retrofit investment}

Before proceeding with the financial viability of different packages of energy efficiency measures, a pre-test for assessing the economic efficiency of each one of the improvement measures was required. The simple Payback (SPB) method, which measures how long it takes to recover investment costs, is usually utilised. As a rule of thumb, an investment that has an SPB shorter than the useful live of the building or the building system generally signals an economic investment, letting aside the time value of money. Otherwise, it should be rejected.

Table 7 presents the payback periods, annual savings and investment costs of the efficiency measures EM1 to EM4. It shows that EM1 has the longest payback period (91.18 years), EM4 the shortest payback (3.56 years) and the payback periods of EM2 and EM3 are quite similar, 24.69 and 23.31 years, respectively. Owing to the fact that the price of KWh of electricity is much higher than that of natural gas, the annual savings of EM1 are even lower than those of EM4. As indicated in Table 6, energy savings come almost totally from natural gas sources in the former and from electrical sources only in the latter. Nonetheless,

Table 7. Investment costs, annual savings and Simple Payback of the efficiency measures EM1 to EM4

\begin{tabular}{|l|c|c|c|c|}
\hline & EM1 & EM2 & EM3 & EM4 \\
\hline Investment cost $(€)$ & $91,179.18$ & $51,292.58$ & $47,545.87$ & $5,600.00$ \\
\hline Annual savings $(€)$ & $1,039.90$ & $2,077.28$ & $2,040.24$ & $1,574.47$ \\
\hline $\begin{array}{l}\text { Simple payback } \\
\text { (years) }\end{array}$ & 91.18 & 24.69 & 23.31 & 3.56 \\
\hline
\end{tabular}

as can also be constructed from Table 6, the reduction in final energy consumption is rather low $(-5.4 \%)$ for a relatively large amount of investment $(91,179.18 €)$. This poor result has mostly to do with the high external wall areato-the useful heated area ratio (see Appendix A). Thus, the efficiency measure EM1 is rejected from a financial point of view and even from a macroeconomic perspective if one considers the enormous financial burden that represents the Government's energy and climate targets within a thirty-year horizon. As the SPB of EM2 and EM3 are both lower than those of the corresponding building elements' useful lives, the options that can be analysed for eventual intervention in the building are the alternative packages EM2+EM4 and EM3+EM4, for EM2 and EM3 are mutually exclusive investments (roof insulation). Table 7 also indicates that the efficiency measures EM2 and EM3 have almost the same annual savings but EM3 has both a lower investment cost $(3,746.71 €)$ and lower payback period. Therefore, the financial assessment was undertaken for the energy package EM3+EM4. As can be constructed from Table 7, the investment costs and annual savings of this energy efficiency package amount to, respectively, 53,145.87 € and 3,614.91 €. The operation and maintenance costs, replacement costs and the residual value were the same of those used for EM4. Applying Equation (3), the IRR presented a value of $4.83 \%$, which was higher than the $4 \%$ real discount rate used for the analysis.

As a robustness check, the IRR value was compared with average capital market interest rates in the Euro area and, in particular, those of Portugal. The headline bank interest rates in the Euro area have been continuously decreasing since 2008, despite a slightly increasing trend in the two-year period 2010-2011. According to the figures provided by the European Central Bank (2020) for the Euro area, the interest rate for new loans to corporations has decreased from $6.03 \%$ in September 2008 to $1.46 \%$ in March 2020 and the one for new loans to household for house purchase has decreased from 5.55\% to 1.39\% in the same period. Data drawn from Pordata (Pordata, 2020) indicated that the average mortgage interest rate in Portugal in the period 2010-2019 was 2.49\% (average for the period) and the average annual inflation rate, as measured by the Consumer Price Index, was 1.18\% in the same period. Thus, the IRR value expressed in nominal prices was roughly $4.83+1.18=6.01 \%$. As the selection of the energy price development is on the conservative side, the yield of an investment of just over $6 \%$ seems to be a fairly attractive financial return. Furthermore, EM3 does not interfere (i.e. no value of waiting) with further improvement measures in the building technical systems (e.g. heating system, cooling system and energy-efficient equipment) and EM4 has a short payback period.

\subsection{Reduction in primary energy consumption}

The efficiency of the building retrofit investment can also be seen at the macroeconomic (social) perspective i.e. reduction in primary energy consumption. Primary en- 
ergy consumption is the standard measure for assessing the energy efficiency strategy of an economy or a sector. Primary energy factors (PEF) are used for converting final energy consumption into primary energy consumption. According to the Ministerial Decision No. 15793-D/2013 (Government Gazette, 2013e) the PEF for electricity is $2.5 \mathrm{KWhpe} / \mathrm{KWh}$ and that of natural gas is $1 \mathrm{KWhpe/}$ KWh. As can be constructed from Tables 5 and 8, the primary energy consumption of the building implemented with the energy efficiency package EM3+EM4 is $258.59 \mathrm{KWhpe} / \mathrm{m}^{2} \mathrm{y}$, and that of the of the building (without project) is $292.23 \mathrm{KWhpe} / \mathrm{m}^{2} \mathrm{y}$. Considering that the building heated area is $1,362.44 \mathrm{~m}^{2}$ (see Annex A), the reduction in primary energy consumption is $11.5 \%$

Table 8. Final energy consumption of the building with the efficiency package EM1+EM4 (KWh)

\begin{tabular}{|l|c|}
\hline Lighting & $23,421.49$ \\
\hline Equipment & $60,156.22$ \\
\hline Cooling & $7,991.33$ \\
\hline Heating & $114,301.78$ \\
\hline DHW & $3,635.57$ \\
\hline Total consumption & $209,506.4$ \\
\hline
\end{tabular}

One way to assess the energy efficiency of the proposed building retrofit investment is to compare the reduction in primary energy consumption with the investment-to- the building construction cost ratio. The EPBD (and the Portuguese legislation) do not provide thresholds for energy renovations in buildings. Nor do they define what constitute light (minor) and medium (moderate) renovations. Major renovations, as defined in the EPBD recast, are interventions in a building where: 1) the investment cost relating to the building systems and/or the building envelope is higher than $25 \%$ of the value of the building, excluding the value of the land; 2) or more than $25 \%$ of the area of the building envelope undergoes renovation works. In Portugal, the first approach is used for the definition of major renovations. In order to compare the outcome of different renovations measures between EU Member countries, the EU ZEBRA2020 project (ZEBRA2020, 2016) developed the indicator of "major renovation equivalent" and assumed that, with major renovations, a building's final energy demand for heating can be reduced by 50 to $80 \%$ (range depending on the country and according to the current efficiency of the building stock).

It is proposed here that an energy retrofit investment is efficient, at the macro level perspective, when the value of primary energy reduction (in percentage terms) is at least double than the investment-to- the building construction cost ratio, also measured in percentage terms. Construction cost of buildings for conditioned house renting purposes was, for the year $2020,654.74 € / \mathrm{m}^{2}$ in the geographic location of the building under study (Statistics Portugal, 2019). This was the construction cost considered for the building useful area. The gross floor area of the building is $2,715.64 \mathrm{~m}^{2}$ and; the construction cost of the remaining building areas $\left(\right.$ per $\mathrm{m}^{2}$ ) was estimated at $50 \%$ of that of the building useful area. Thus, the building construction cost amounted to $1,335,041.05 €$; and the investment-tothe building construction cost ratio was $4.0 \%$, or about $35 \%$ of the value of the primary energy consumption reduction. Considering that the provisions of the EED also advocate a step by step procedure for the renovation of national building stock, the retrofit investment appears to show a promising return at the macro level point of view.

\section{Conclusions}

Residential buildings are responsible for about two-thirds of the final energy consumption of the European building stock. Thus, the major focus of the MS energy renovation strategies will naturally be on residential buildings. Portugal presents a distinct consumption pattern when compared to that of the EU. Residential and service buildings in Portugal contributed, respectively, $16 \%$ and $13 \%$ to total energy consumption in 2016. In terms of the evolution of these two segments in the national energy consumption balance, the residential segment experienced a decrease of $19.2 \%$ in the period 2006-2016 and the service segment showed a decrease of $10.2 \%$ in the same period. A clear trend of stagnation has been observed in the latter segment since 2013. As office buildings constructed before the implementation of the first thermal regulation in Portugal represent, respectively, about $20.1 \%$ of the service segment's built-up area and about $28.7 \%$ of the service building segment's total energy consumption, one can realize the relevance of this cohort of buildings for attaining the country's energy and climate goals.

The comparative methodology framework stated in the EU Delegated Regulation No. 244/2012 is addressed to MS. The cost optimal level is calculated to set up minimum energy performance requirements applicable at national level. This harmonised methodology with its emphasis on investment's Net Present Value is more appropriate for projects with high initial investment costs, and at the macro level point of view. This approach is not suitable at the private investor's perspective. For this type of investor, the main concerns are the up-front investment and the cost of capital reflecting the expected return of an investor. As the building owner's organisation is a noncommercial private investor, the IRR method combined with the Payback method were used for the financial evaluation of this study.

This research has assessed the energy performance of an existing large office building constructed before the entry into force of the first thermal regulation in Portugal in 1991. Four different efficiency measures were selected to improve the building's energy performance. A financial evaluation combined with a dynamic energy simulation was undertaken to choose the best option of energy retrofit solutions. A pre-test, by using the simple Payback method, showed that the efficiency measure concerning the insulation of the external wall was financially inefficient. Thus, this energy efficiency measure was cast-off of the retro- 
fit options for further analysis through the IRR method. The best option of energy retrofit solutions was a package consisting of roof insulation and the installation of an energy-efficient equipment for the domestic hot water system. This energy retrofit investment showed a positive financial return ( $4.83 \%$ in real terms), when compared with the real discount rate of $4 \%$ used for the analysis. This study corroborates the results of previous studies (e.g. Kapsalaki et al., 2012; Ferrari \& Beccali, 2017) that show that retrofit solutions that do not include improvements on the building envelope are generally the most cost-effective options. The results that emerge from the study also indicate that the financial performance of a retrofit solution can be strongly affected by the value of discount rate selected. In the cost-benefit mix of energy retrofit investment, annual savings come from reduction in energy consumption. The higher the discount rate selected, the lower the present value of annual savings. As the present value of annual savings also decrease with increasing time along the study period, the selection of a high discount rate has serious implications on the financial attractiveness of a long-term investment project.

This study can help to inform public policy in two ways. The first has to do with the compliance with the obligations contained in the Article 4 of the EED. The review of EU and Portugal's policy frameworks indicates that Portugal's $2^{\text {nd }}$ LTRS does not provide any information on the cost-effectiveness approach to renovation. Like in most MS, the majority of building renovation projects in Portugal is in the light to-moderate- range. Thus, a staged approach to renovation appears to be more compatible (at least in the medium-term horizon) with the reality of the market. An analysis that identifies profitable approaches to renovation in specific building clusters (and with different renovation scenarios) would be an effective way to help to motivate the stakeholders of the building renovation market. The second way (connected to the first) has to do with the link between national public financial aid available for the initial investment and the country's long-term energy and climate goals. This study suggests that an approach to assess the effectiveness of energy retrofit investment, at the macroeconomic pointed of view, is to compare the investment-to-the building construction cost ratio with the rate of primary energy reduction.

The paper has some limitations. Although the building is representative of a particular building cluster, the study covers one (Zone W3V2) of the six climate zones of Portugal mainland only. The study could be extended to buildings belonging to the same building archetype in other climate zones. This is not an easy undertaking, as each building has its own particularities. Regarding studies related to national strategies, they would be based on a wide sample of case studies on representative building archetypes. These would constitute useful complements to studies dealing with the macroeconomic and financial evaluation of the national building stock.

\section{Funding}

No funding was received for this study.

\section{Author contributions}

All the authors conceived the study and were responsible for the design and development of the data analysis. SC, $\mathrm{CA}$ and OS were responsible for data collection and interpretation. JL was responsible for the economic assessment.

\section{Disclosure statement}

We thereby declare that we do not have any competing financial, professional, or personal interests from other parties.

\section{References}

Aguiar, R., \& Graça, J. (2019, February 14). Custo-ótimo: residências isoladas novas. Relatório em cumprimento da Diretiva 2010/31/ EU (EPBD) e Regulamento Delegado (UE) n. ${ }^{\circ}$ 244/2012, relativo ao cálculo dos níveis ótimos de rentabilidade dos requisitos mínimos de desempenho energético dos edifícios e componentes de edifício. DGEG, Lisbon, Portugal (in Portuguese).

American Society of Heating, Refrigerating and Air-Conditioning Engineers. (2017). ANSI/ASHRAE Standard 140-2017. Standard method of test for the evaluation of building energy analysis computer programs. ASHRAE, Atlanta, GA.

Bogdan, A., \& Ilektra, K. (2013). Implementing cost-optimal methodology in EU countries: lessons from three case studies. Building Performance Institute Europe (BPIE). https://www. bpie.eu/publication/implementing-the-cost-optimal-methodology-in-eu-countries/

Capros, P., De Vita, A., Tasios, N., Siskos, P., Kannavou, M., Petropoulos, A., Evangelopoulou, S., Zampara, M., Papadopoulos, D., Paroussos, L., Fragiadakis, K., Tsani, S., Fragkos, P., Kouvaritakis, N., Höglund-Isaksson, L., Winiwarter, W., Purohit, P., Gomez-Sanabria, A., Frank, S., Forsel, N., Gusti, M., Havlík, P., Obersteiner, M., Witzke, H., \& Kesting, M. (2016). EU energy, transport and GHG emissions - trends to 2050 (A Report prepared for the DirectorateGeneral for Climate Action and the Directorate-General for Mobility and Transport by E3M-Lab of the ICCS-NTUA). Greece. https://ec.europa.eu/energy/sites/ener/files/documents/20160713\%20draft_publication_REF2016_v13.pdf

Castellazi, L., Zangheri, P., Paci, D., Economidou, M., Labanca, N., Ribeiro Serrenho, T., Panev, S., Zancanela, P., \& Broc, J. S. (2019). Assessment of second long-term renovation strategies under the Energy Efficiency Directive. Joint Research Centre (JRC) for Policy Report, the European Commission. https:// ec.europa.eu/jrc/en/publication/assessment-second-longterm-renovation-strategies-under-energy-efficiency-directive

Chapman, R. E., \& Kasi, M. (2012). Benefits of using ASTM building economics standards for the design, construction, and operation of constructed facilities (NIST Special Publication No. 1098). US Department of Commerce National Institute of Standards and Technology.

Conci, M., Thaleia, K., van den Dobbelsteen, A., \& Schneider, J. (2019). Trade-off between the economic and environmental impact of different decarbonisation strategies for residential buildings. Building and Environment, 155, 137-144. https://doi.org/10.1016/j.buildenv.2019.03.051 
Cype Ingenieros. (2020, May 15). Gerador de preços para a construção civil, Portugal. http://www.geradordeprecos.info/

Directorate-General for Energy and Geology. (2013). Cálculo dos níveis ótimos de rentabilidade dos requisitos mínimos de desempenho energético dos edifícios e componentes de edifícios: edifícios hoteleiros. DGEG \& ADENE, Lisbon, Portugal (in Portuguese).

Directorate-General for Energy and Geology. (2019). Long-term national strategy for the mobilisation of investment in building renovation. DGEG, Lisbon, Portugal.

DGEG, \& ADENE. (2019). Calculation of cost-optimal levels of the minimum energy performance requirements of buildings and building elements: hotel buildings. DGEG \& ADENE, Lisbon, Portugal.

European Central Bank. (2020, July 3). Euro area bank interest rate statistics - May 2020. https://www.ecb.europa.eu/press/ pr/stats/mfi/html/ecb.mir2005 82d80452ce.en.html

Economidou, M. (2011). Europe's building under the microscope. BPIE Publications.

Economidou, M., \& Bertoldi, P. (2014). Financing energy renovations in the European building stock. JRC for Policy Report, the European Commission. https://e3p.jrc.ec.europa.eu/articles/financing-energy-renovations-european-building-stock

European Court of Auditors. (2020). Energy efficiency in buildings: greater focus on cost-effectiveness is still needed (Special Report). European Court of Auditors, Luxembourg. https:// www.eca.europa.eu/Lists/ECADocuments/SR20_11/SR_Energy efficiency_in_buildings_EN.pdf

European Parliament, \& Council of the European Union. (2002). Directive 2002/91/EC of the European Parliament and of the Council of 16 December 2002 on the energy performance of buildings. https://eur-lex.europa.eu/LexUriServ/LexUriServ. do?uri=OJ:L:2003:001:0065:0071:EN:PDF

European Parliament, \& Council of the European Union. (2006). Directive 2006/32/EC of the European Parliament and of the Council of 5 April 2006 on energy end-use efficiency and energy services and repealing Council Directive 93/76/EEC. https://eur-lex.europa.eu/legal-content/EN/ ALL/?uri=CELEX\%3A32006L0032

European Parliament, \& Council of the European Union. (2010). Directive 2010/31/EU of the European Parliament and of the Council of 19 May 2010 on the energy performance of buildings amending Directive 2002/91/EC. https://eur-lex. europa.eu/legal-content/EN/TXT/?uri=CELEX\%3A0201 0L0031-20210101

European Parliament, \& Council of the European Union. (2012a). Commission Delegated Regulation No 244/2012/EC of 16 January 2012 supplementing Directive 2010/31/EC of the European Parliament and of the Council on the energy performance of buildings by establishing a comparative methodology framework for calculating cost-optimal levels of minimum energy performance requirements for buildings and building elements. https://eur-lex.europa.eu/legal-content/GA/ TXT/?uri=CELEX:32012R0244

European Parliament, \& Council of the European Union. (2012b). Directive 2012/27/EU of the European Parliament and of the Council of 25 October 2012 on energy efficiency, amending Directives 2009/125/EC and 2010/30/EU and repealing Directives 2004/8/EC and 2006/32/EC. https://eur-lex. europa.eu/legal-content/EN/TXT/?uri=celex\%3A32012L0027

European Parliament, \& Council of the European Union. (2016). Factsheets: buildings in EU countries: Portugal. https:// ec.europa.eu/energy/sites/ener/files/documents/port.pdf
European Parliament, \& Council of the European Union. (2018a). Directive 2018/2002/EU of the European Parliament and of the Council of 11 December 2018 amending Directive 2012/27/EU on energy efficiency. https://eur-lex.europa.eu/legal-content/ EN/TXT/?uri=uriserv\%3AOJ.L_.2018.328.01.0210.01.ENG

European Parliament, \& Council of the European Union. (2018b). Directive 2018/844/EU of the European Parliament and the Council of 30 May 2018 amending Directive 2010/31/EU on the energy performance of buildings and Directive 2012/27/EU on energy efficiency. https://eur-lex.europa.eu/legal-content/ EN/TXT/?uri=uriserv\%3AOJ.L_.2018.156.01.0075.01.ENG

European Parliament, \& Council of the European Union. (2018c). Directive 2018/2001/EU of the European Parliament and of the Council of 11 December 2018 on the promotion of the use of energy from renewable sources (recast). https://eurlex.europa.eu/legal-content/EN/TXT/PDF/?uri=CELEX:3201 $8 \mathrm{~L} 2001 \&$ from $=\mathrm{EN}$

European Parliament, \& Council of the European Union. (2019). Clean energy for all European package. https://op.europa.eu/ en/publication-detail/-/publication/b4e46873-7528-11e99f05-01aa75ed71a1/language-en

European Parliament, \& Council of the European Union. (n.d.). EU Building Stock Observatory. https://ec.europa.eu/energy/topics/ energy-efficiency/energy-efficient-buildings/eu-bso_en

Fabbri, M., De Groote, M., \& Rapf, O. (2016). Building renovations passport - customised roadmaps towards deep renovations and better homes. BPIE. http://bpie.eu/wp-content/ uploads/2017/01/Building-Passport-Report_2nd-edition.pdf

Ferrari, S., \& Beccali, M. (2017). Energy-environmental and cost assessment of a set of strategies for retrofitting a public building toward nearly zero-energy building target. Sustainable Cities and Society, 32, 226-234. https://doi.org/10.1016/j.scs.2017.03.010

Ferreira, M., Almeida, M., Rodrigues, A., \& Silva, S. M. (2016). Comparing cost-optimal and net-zero energy targets in building retrofit. Building Research \& Information, 44(2), 188-201. https://doi.org/10.1080/09613218.2014.975412

Fragoso, R., \& Baptista, N. (2016). EPBD implementation in Portugal: status in December 2016. Concerted Action, Energy Performance of Buildings, ADENE.

Government Gazette. (1990). Decree/Law 40/90 of 6 February 1990. https://dre.pt/application/conteudo/334611

Government Gazette. (2006a). Decree/Law 78/2006 of 4 April 2006. https://dre.pt/application/conteudo/672458

Government Gazette. (2006b). Decree/Law 79/2006 of 4 April 2006. https://dre.pt/application/conteudo/672459

Government Gazette. (2006c). Decree/Law 80/2006 of 4 April 2006. https://dre.pt/application/conteudo/672456

Government Gazette. (2013a). Decree/Law 118/2013 of 20 August 2013: system of buildings' energy performance and certification, regulation of residential building energy performance, regulation of non-residential building energy performance (in Portuguese). https://dre.pt/application/conteudo/499237

Government Gazette. (2013b). Ministerial Decision $n^{\circ} 15793$ E/2013 of 2 December 2013.

https://dre.pt/application/conteudo/2975218

Government Gazette. (2013c). Ministerial Decision $n^{\circ} 15793-$ F/2013 of 2 December 2013.

https://dre.pt/application/conteudo/2975219

Government Gazette. (2013d). Ministerial Order no 349-D/2013 of 2 December. https://dre.pt/application/conteudo/263693

Government Gazette. (2013e). Ministerial Decision $n^{\circ}$ 15793D/2013 of 2 December 2013.

https://dre.pt/application/conteudo/263693 
Government of Portugal. (2019). Roadmap for carbon neutrality 2050 (RNC50): long-term strategy for carbon neutrality of the Portuguese economy (Report No. 262/2019). Government Publications, Lisbon, Portugal.

Government of Portugal. (2020a). National Energy and Climate Plan 2030 (PNEC 2030): Resolution of Council of Ministers n'53/2020 published in Government Gazette, 10 July 2020. Lisbon, Portugal

Government of Portugal. (2020b). Estratégia de Longo Prazo para a Renovação de Edifícios (Public discussion document). Government Publications (in Portuguese).

Hermelink, A. H., \& de Jager, D. (2015). Evaluating our future the crucial role of discount rates in European Commission energy system modelling. The European Council for an Energy Efficient Economy \& Ecofys. https://www.eceee.org/static/ media/uploads/site-2/policy-areas/discount-rates/evaluatingour-future-report.pdf

Intergovernmental Panel on Climate Change. (2015). Climate Change, 2014: Synthesis Report. Contribution of Working Groups I, II and III to the Fifth Assessment Report of the Intergovernmental Panel on Climate Change. IPCC, Geneva, Switzerland. https://www.ipcc.ch/site/assets/uploads/2018/05/ SYR_AR5_FINAL_full_wcover.pdf

Kapsalaki, M., Leal, V., \& Santamouris, M. (2012). A methodology for economic efficient design of Net Zero Energy Buildings. Energy and Buildings, 55, 765-778.

https://doi.org/10.1016/j.enbuild.2012.10.022

Kamari, A., Jensen, S. R., Corrao, R., \& Kirkegaard, P. H. (2019). A holistic multi-methodology for sustainable renovation. International Journal of Strategic Property Management, 23(1), 50-64. https://doi.org/10.3846/ijspm.2019.6375

Lopes, A., \& Cova, S. (2018) Simulação dinâmica de um edíficio de comércio e serviços. Polytechnic Institute of Bragança (in Portuguese).

Pinto, A. (2014, December). Estudo de cálculo dos níveis ótimos de rentabilidade dos requisitos mínimos de desempenho energético dos edifícios e componentes de edifícios (Report No. 473/2014). DED/NAICI, DGEG, Lisbon, Portugal (in Portuguese).

Pordata. (2020, May 15). Interest rates on new loan operations (annual average) to individuals: total and by purpose type. https://www. pordata.pt/en/Portugal/Interest+rates+on+new+type-2845
Portuguese Energy Agency. (2018, July). Energy efficiency trends and policies in Portugal. https://www.odyssee-mure.eu/publications/national-reports/energy-efficiency-portugal.pdf

Ramesh, T., Prakash, R., \& Shukla, K. K. (2010). Life cycle energy analysis of buildings: an overview. Energy and Buildings, 42, 1592-1600. https://doi.org/10.1016/j.enbuild.2010.05.007

Rodrigues, F., Parada, M., Vicente, R., Oliveira, R., \& Rodrigues, A. (2015). High energy efficiency retrofits in Portugal. Energy Procedia, 83, 187-196. https://doi.org/10.1016/j.egypro.2015.12.209

Ruegg, R., \& Marshall, H. (1990). Building economics: theory and practice $\left(1^{\text {st }}\right.$ ed.). Springer Science+Business Media. https://doi.org/10.1007/978-1-4757-4688-4

Santos, C., \& Matias, L. (2006). Coeficientes de transmissão térmica de elementos da envolvente de edifícios-ITE 50. National Laboratory for Civil Engineering, ICT, Lisbon (in Portuguese).

Statistics Portugal. (2019). Notice $N^{o}$ 15225/2019: coeficientes de atualização dos diversos tipos de arrendamento rural e urbano a vigorar no ano de 2020. INE, Lisbon (in Portuguese). http://dre.pt/application/conteudo/125030927

Steinbach, J., \& Staniaszek, D. (2015, May). Discount rates in energy system analysis (Discussion paper). BPIE. https://bpie.eu/ wp-content/uploads/2015/10/Discount_rates_in_energy_system-discussion_paper_2015_ISI_BPIE.pdf

Tadeu, S., Rodrigues, C., Tadeu, A., Freire, F., \& Simões, F. (2015). Energy retrofit of historic buildings: environmental assessment of cost-optimal solutions. Journal of Building Engineering, 4, 167-176. https://doi.org/10.1016/j.jobe.2015.09.009

Tadeu, S., Alexandre, R., Tadeu, A., Antunes, C., Simões, N. A. V., \& da Silva, P. (2016). A comparison between cost optimality and return on investment for energy retrofit buildings - a real options perspective. Sustainable Cities and Society, 21, 12-25. https://doi.org/10.1016/j.scs.2015.11.002

Vasconcelos, A., Pinheiro, M., Manso, A., \& Cabaço, A. (2015). A Portuguese approach to define reference buildings for cost-optimal methodologies. Applied Energy, 140, 316-328. https://doi.org/10.1016/j.apenergy.2014.11.035

ZEBRA2020. (2016). Nearly zero-energy building strategy 2020: strategies for a nearly zero-energy building market transition in the European Union. https://www.zebra2020.eu/website/ wp-content/uploads/2014/08/ZEBRA2020_Strategies-fornZEB_07_LQ_single-pages-1.pdf

\section{Appendix}

\section{Appendix A. Building areas $\left(\mathbf{m}^{2}\right)$}

\begin{tabular}{|l|c|}
\hline Ground floor & $1,320.98$ \\
\hline First floor & $1,324.96$ \\
\hline Total floor area & $2,715.64$ \\
\hline Total useful area & $1,362,44$ \\
\hline Exterior wall area & $2,377.97$ \\
\hline Exterior glazed area & 368.39 \\
\hline Garage gates area & 170.51 \\
\hline Wall area in contact with the ground & 288.26 \\
\hline Flat roof area & 681.22 \\
\hline Sloping roof area & $1,391.13$ \\
\hline
\end{tabular}

